\title{
Changes in the Levels of Glycoalkaloids and Nitrates After the Dehydration of Cooked Potatoes
}

\author{
Elżbieta Rytel
}

Published online: 13 November 2012

(C) The Author(s) 2012. This article is published with open access at Springerlink.com

\begin{abstract}
The aim of this study was to investigate the effects of various processes used during the laboratory production of dehydrated cooked potato on the concentration of glycoalkaloids ( $\alpha$-chaconine and $\alpha$-solanine) and nitrates in the raw material, intermediate and final product. In the raw material, half-products and in the final products there were determined glycoalkaloids contents ( $\alpha$-chaconine and $\alpha$-solanine) with the use of HPLC method and nitrates contents colorimetrically by RQflex apparatus. During the laboratory production of dehydrated potato, glycoalkaloid and nitrate content in processed potatoes decreased. TGA decreased most after peeling (30\%), blanching (28\%) and pre-drying (25\%). Nitrate content decreased significantly after blanching $(21 \%)$ and after predrying (18\%).
\end{abstract}

Resumen El propósito de este estudio fue investigar los efectos de varios procesos usados durante la producción en laboratorio de papa cocinada deshidratada con respecto a la concentración de glicoalcaloides ( $\alpha$-chaconina y $\alpha$ solanina) y nitratos en el material crudo, intermedio y el producto final. En el material crudo, en los intermedios y en los finales se determinaron los contenidos de glicoalcaloides ( $\alpha$-chaconina y $\alpha$-solanina) con el uso del método de HPLC, y el contenido de nitratos fue colorimétricamente mediante el aparato de RQflex. Durante la producción en el laboratorio de papa deshidratada, el contenido de glicoalcaloides y nitrato en papas procesadas disminuyó. TGA disminuyó más durante el descascarado (30\%), en el blanqueado

\footnotetext{
E. Rytel $(\bowtie)$

Department of Food Storage and Technology,

Wrocław University of Environmental and Life Sciences,

Chełmońskiego 37/41,

51-630 Wrocław, Poland

e-mail: elzbieta.rytel@wnoz.up.wroc.pl
}

(28\%) y en el pre-secado (25\%). El contenido de nitratos disminuyó significativamente después del blanqueado (21\%) y después del pre-secado (18\%).

Keywords Potato $\cdot$ Glycoalkaloids $\cdot$ Nitrates $\cdot$ Dehydrated cooked potato

\section{Introduction}

Potato is popular among consumers all over the world its high content of nutrients, such as carbohydrate compounds, protein, vitamins (mainly vitamin $\mathrm{C}$ ) and minerals, but also its high gustatory and olfactory qualities. In addition, potato gives a high yield under different climatic and soil conditions, so can be grown in many countries (Lisińska et al. 2009; Rytel et al. 2011). Potatoes, like most edible plants, also contain some undesirable substances which are either naturally occurring ingredients or are products of metabolism by environmental stresses (Rytel 2010).

These compounds include antinutritional substances hindering the absorption of nutrients by the body, and toxins which may cause poisoning and damage bodily functions (Lewicki 2008; Rytel 2010). The naturally occurring toxic substances in potatoes include glycoalkaloids, chiefly $\alpha$-chaconine and $\alpha$ solanine (Friedman and Dao 1992; Friedman and Levin 2009). $\alpha$-Solanine is about $30 \%$ less than $\alpha$-chaconine. $\alpha$-Solanine and $\alpha$-chaconine differ in sugar components. In $\alpha$-solanine solatriose is sugar component, composed of glucose, galactose and rhamnose, combined with solanidine by galactose; $\alpha$ chaconine consists of two molecules of rhamnose and glucose and is connected with solanidine (Cieślik 1997; Haase 2010; Friedman and Dao 1992; Friedman and McDonald 1997; Ostry et al. 2010). High content of glycoalkaloids, above $20 \mathrm{mg} 100 \mathrm{~g}$ fresh tuber weight, is very undesirable in potatoes 
that are meant for consumption or food processing (Ginzberg et al. 2009). However, below $10 \mathrm{mg} 100 \mathrm{~g}$, they have a beneficial effect on the taste and smell of potato tubers (Leszczyński 2000). In general, potatoes contain low amounts of glycoalkaloids, below $20 \mathrm{mg} 100 \mathrm{~g}$ fresh tuber weight and glycoalkaloid poisonings after ingestion of potatoes are rare (Friedman 2006; Pęsa et al. 2006; Rytel et al. 2005). These compounds are usually located in the skin and just below its surface, so peeling of tubers may reduce their content by up to 50-70 \% (Rytel 2012; Tajner-Czopek et al. 2008; TajnerCzopek et al. 2011).

Nitrates comprise another group of compounds that naturally occur in potatoes. In Central Europe potato tubers contain from 100 to $740 \mathrm{mg} \mathrm{NaNO} \mathrm{kg}^{-1}$, and on average 150-300 mg $\mathrm{NaNO}_{3} \mathrm{~kg}^{-1}$ (Cieslik 1995; Murawa et al. 2008), which is several times less than in other vegetables: green lettuce (1500-3000 mg kg-1), cabbage (from 1000 to $6500 \mathrm{mgkg}^{-1}$ ), parsley root $\left(400-1100 \mathrm{mgkg}^{-1}\right)$, and beetroot (1400-3200 $\mathrm{mgkg}^{-1}$ ) (Murawa et al. 2008). The permissible amount of these compounds in potatoes produced for human consumption should not exceed $200 \mathrm{mg} \mathrm{NO}_{3}^{-} \mathrm{kg}^{-1}$ (274 mg $\mathrm{NaNO}_{3} \mathrm{~kg}^{-1}$ ) (Hill 1999). Nitrate is not toxic to humans, but may be reduced by intestinal microflora to nitrate III, which participates in the production of carcinogenic nitrosamines (Leszczyński 2000; Rytel et al. 2011). Therefore the nitrate concentration in potatoes should be closely monitored, especially as it can be significantly increased by climatic factors, agrotechnical conditions, the intensity of nitrogen fertilization, or inappropriate storage conditions (Amr and Hadidi 2001; Cieslik 1994; Ierna 2009; Zgórska et al. 2006). It is important to constantly control the concentration of toxic or antinutritional compounds in the raw material, and also during technological processes used in the production of chips, french fries or dehydrated potato products that influence the content of these compounds. Most toxic or antinutritional compounds are located in the skin, hence their significant reduction in the initial stages of production, including washing and peeling potatoes (Rytel et al. 2005; Pęksa et al. 2006; Rytel 2012). Many authors (Cieslik 1994; Friedman 2006; Friedman and Levin 2009; Knuthsen et al. 2009; Pęksa et al. 2006; Rytel et al. 2005; Zgórska et al. 2006) that deal with the problem of antinutritional substances emphasise the fact that thermal processes, such as blanching and cooking reduce the levels of glycoalkaloids and nitrates in processed potatoes.

A more pronounced decrease in anti-nutritional compounds has been observed after frying, mainly due to high temperatures (above $170^{\circ} \mathrm{C}$ ) and good solubility of these compounds in fat (Friedman 2006; Pęksa et al. 2006; Rytel et al. 2005). Papers on the content of glycoalkaloids and nitrates provide little data on the effects of potato dehydration, whether in raw material, intermediates or finished products. However, it seems important to understand the factors that affect the levels of glycoalkaloids or nitrates in processed potatoes, especially as they are often an intermediate product used as the main ingredient of further processed food, such as dumplings, croquettes, or potato chips made from potato dough.

The aim of this study was to investigate the effects of various stages used during the laboratory production of dehydrated cooked potato on the concentration of glycoalkaloids ( $\alpha$-chaconine and $\alpha$-solanine) and nitrates in the raw material, intermediates and final product.

\section{Material and Methods}

\section{Raw Material}

Four varieties of potato, two of Polish origin (Denar, Pasat), Dutch variety (Innovator) and Germany Karlena variety have been used in the experiment. The potato samples coming from the storage room at a factory for potato products. Potatoes were stored in bulk at a temperature of $6{ }^{\circ} \mathrm{C}$. There were sampled four times from the factory store in 2009/2010 (December and April) and 2010/2011 (December and April). Each sample weighed $50 \mathrm{~kg}$, dried potato processing was repeated threefold.

\section{Method of Dehydrated Production in Laboratory Conditions}

The potatoes were washed then peeled $(1.5 \mathrm{~mm})$ using a laboratory carborundum peeler. Peeled potatoes were cut into halves (only large tubers) and blanched in water at $75{ }^{\circ} \mathrm{C}$ for $20 \mathrm{~min}$ and then cooled in water at $20^{\circ} \mathrm{C}$. After this process, the potatoes were steamed for about $30 \mathrm{~min}$. The steamed potato mass was crushed using a sieve with a mesh of $0.5 \times 0.5 \mathrm{~mm}$ and dried at $160{ }^{\circ} \mathrm{C}$ in a laboratory oven for $2 \mathrm{~h}$. Then the samples were additionally dried at $50{ }^{\circ} \mathrm{C}$ for about $12-14 \mathrm{~h}$ to obtain a moisture content of $8 \%$. $1 \mathrm{~kg}$ samples of potato were taken during each stage of laboratory processing (Fig. 1).

Potato Sample Preparation for Analysis Raw, peeled, blanched and steamed samples of potato were freeze-dried (using an Edwards freezer). The obtained dry material was ground in an electric grinder and used to determine the concentrations of $\alpha$-solanine, $\alpha$-chaconine and nitrates.

\section{Concentrations of $\alpha$-Solanine and $\alpha$-Chaconine}

Apparatus A high-pressure liquid chromatograph HPLC (pro Star) was used (Varian, Walnut Creek, CA, USA). The HLPC was equipped with a UV detector - 310 type, Microsorb NH2 analytical column $(25 \times 46 \mathrm{~cm}$ LD) (Rainin Instrument, Woburn, Ma, USA), and a computer system for monitoring the chromatograph (Varian Chromatography System). 
Fig. 1 The diagram of analytical studies

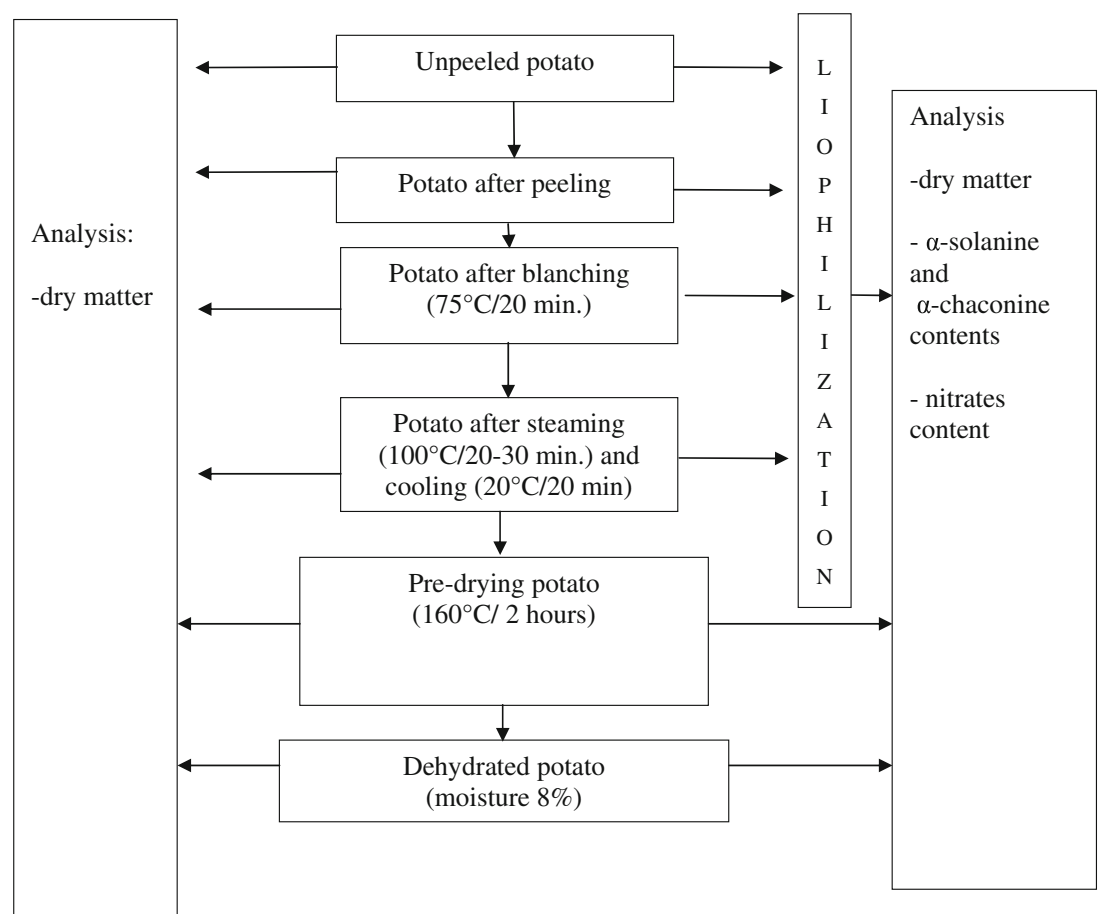

Conditions of Glycoalkaloid Separation A mixture of tetrahydrofuran (Merck, Germany), acetonitrile and water 50:20:30 $+\mathrm{KH}_{2} \mathrm{PO}_{4}(1.02 \mathrm{~g})$ was used as an eluent. The process was carried out at a temperature of $35^{\circ} \mathrm{C}$, with a flow rate of $2 \mathrm{~cm}^{3} \mathrm{~min}^{-1}$ and pressure of $11.3 \mathrm{MPa}$, applying a light wavelength of $208 \mathrm{~nm}$.

Sample Preparation for Chromatographic Analysis The freeze-dried material $(1 \mathrm{~g})$ was homogenized with $4 \mathrm{~cm}^{3}$ of water and $30 \mathrm{~cm}^{3}$ of methanol (Labscan, Ireland) for $2 \mathrm{~min}$, followed by filtration. The filtrate was brought to a final volume of $50 \mathrm{~cm}^{3}$ with methanol. A $5 \mathrm{~cm}^{3}$ aliquot of extract was cleaned up on the SPE column (Bond Elut C18; $500 \mathrm{mg} ; 6.0 \mathrm{~cm}^{3}$, Varian, USA). Glycoalkaloids were rinsed with methanol and evaporated to dryness in a vacuum at a temperature of $50^{\circ} \mathrm{C}$. The resultant residue was dissolved in $1 \mathrm{~cm}^{3}$ of THF:ACN: $\mathrm{H}_{2} \mathrm{O}-50: 20: 30$. Before application into the column, the sample was cleaned using $0.45 \mu \mathrm{m}$ filters. The volume of the injection was $10 \mu$ l. Standard solutions $\left(1 \mathrm{mg} / \mathrm{cm}^{3}\right)$ were prepared by dissolving $10 \mathrm{mg}$ of $\alpha$-solanine and $\alpha$-chaconine (Sigma) in $10 \mathrm{~cm}^{3}$ of methanol. Standard solution was dissolved to obtain samples containing from 1 to $50 \mu \mathrm{g} / \mathrm{cm}^{3}$ of both $\alpha$-solanine and $\alpha$ chaconine. On the column $10 \mu \mathrm{l}$ of solution was injected.

Concentration of Nitrate

Reflectometric method with test strips was used, at a measurement range from 5 to $225 \mathrm{mgkg}^{-1} \mathrm{NO}_{3}$. According to the principle of reflectometry (remission photometry), we measured the reflected light from the strip. In classical photometry, the difference in intensity of emitted and reflected light allows a quantitative determination of the concentration of specific analysis.

Sample Preparation for Nitrate Analysis Nitrate concentrations were determined by reflectometry using a Rqflex analyser (Merck). Determinations were made in $20 \mathrm{~g}$ of distilled water solution containing $5 \mathrm{~g}$ of a dry sample. In the solution we measured nitrate concentrations using test strips.

\section{Analytical Methods}

The dry matter of fresh potato samples and freeze-dried material was determined by the reduced weight after drying at $102^{\circ} \mathrm{C}$ and until constant weight was achieved (AOAC 1995). The nitrate content of the potato tubers was determined colometrically in the potato tubers, intermediates and finished products (Rytel et al. 2005).The quantities of $\alpha$-solanine and $\alpha$-chaconine were determined using the method of Peiksa et al. (2002) and Saito et al. (1990). All the analyses were carried out twice technical replicates.

\section{Statistical Analysis}

The results obtained in the experiment were subjected to statistical calculations in Statistica 9.0 software. We applied a multi-way analysis of variance and Duncan's test $(P \leq$ 0.05 ) for the determination of the significance of differences between means. All experiments were performed in three technological replications from two years of investigation and the present results show the mean of all data combined. 
Table 1 Total glycoalkaloids content (mg $100 \mathrm{~g}^{-1}$ d.m.) in potatoes during dehydration of cooked potatoes

a,b,c,d,e: columns indicate significant differences (Duncan test, $p<0.05$ )

A, B, C, D: rows indicate significant differences (Duncan test, $p<0.05$ )

\section{Results and Discussion}

Laboratory tests used samples from a potato plant store at the beginning of storage (in December) and at the end (April). Potatoes tested in December had a lower content of glycoalkaloids (Table 1). Potatoes used for consumption and for industrial processing are usually stored for a relatively long period of time - about 9 months (Czerko and Zgórska 2008; Lisińska et al. 2009). The length of this period and the conditions in which potatoes are stored affects their glycoalkaloid concentrations (Friedman and McDonald 1997; Love et al. 1994). The longer the storage, the greater the amount of synthesized glycoalkaloid in potatoes (Friedman and McDonald 1997; Love et al. 1994; Sengül et al. 2004). This may be due to the beginning of germination of tubers at the end of the storage period (March-April), as it is harder to maintain lower temperature in storage due to the rising temperature outside (in Central Europe temperature during the day in April is over $10^{\circ} \mathrm{C}$ ) and increased number of sunny days (Czerko and Zgórska 2008; Lisińska and Leszczyński 1989). Higher storage temperatures expose potatoes to stress that induces the synthesis of glycoalkaloids (Friedman and McDonald 1997; Haase 2010).

During the laboratory dehydration of cooked potatoes, the concentration of glycoalkaloids decreased significantly and there were also stated the significant differences during storage (Table 1). Peeling resulted in an approximately $30 \%$ reduction in $\alpha$-chaconine and $\alpha$-solanine in potato tubers (Fig. 2). Glycoalkaloids are located in the skin and around the eyes, so peeling can result in a reduction of these compounds by up to $80-90 \%$. The reductions depends on the depth and peeling technique (Rytel et al. 2005; Tajner-Czopek et al. 2008; Tajner-Czopek et al. 2011). However, even with incomplete removal of the skins, potatoes may lose even 70 80 \% glycoalkaloids (Pęksa et al. 2006; Rytel 2012).

The next stage was blanching. Peeled potatoes were fragmented (large tubers were cut in half) and subjected to thermal processes. The cut potatoes were blanched in water at $75^{\circ} \mathrm{C}$ for $15 \mathrm{~min}$. and then cooled. In industrial practice, different temperatures and times of blanching are used. It depends on the type of the final product, quality of the processed potato and degree of fragmentation. The temperature used during the laboratory production of dehydrated potato was sufficiently

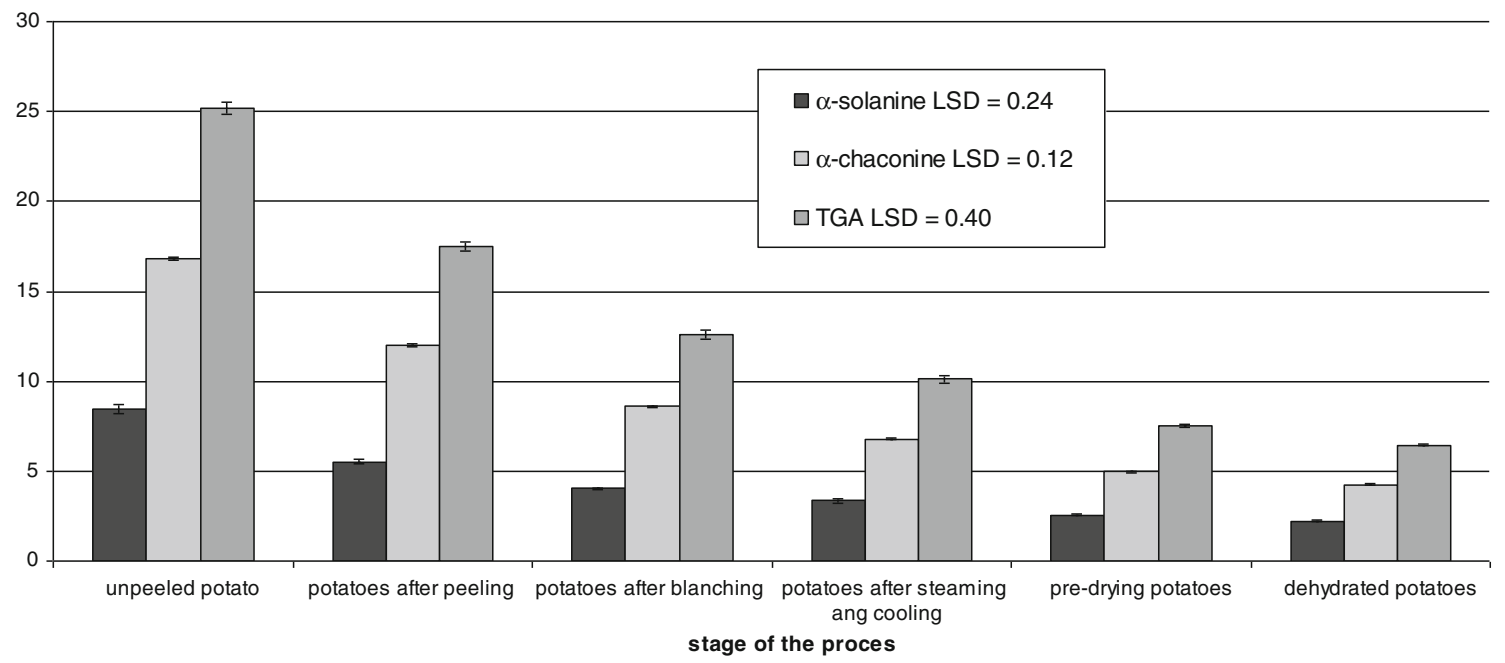

Fig. 2 Total glycolakaloids content (mg $100 \mathrm{~g}^{-1} \mathrm{~d} . \mathrm{m}$.) in potatoes during dehydration of cooked poatoes (mean of 2 years). LSD - indicates significant differences between stages (Duncan test, $p<0.05$ ); \pm SD standard deviation; $n=8$ 
Table 2 Nitrates content (mg $\mathrm{NaNO}_{3} \mathrm{~kg}^{-1}$ d.m.) in potatoes during dehydration of cooked potatoes

a,b,c,d: columns indicate significant differences (Duncan test, $p<0.05$ )

$\mathrm{A}, \mathrm{B}, \mathrm{C}$ : rows indicate significant differences (Duncan test, $p<0.05$ )

\begin{tabular}{|c|c|c|c|c|}
\hline \multirow[t]{2}{*}{ Stage of the process } & \multicolumn{2}{|l|}{$2009 / 2010$} & \multicolumn{2}{|l|}{$2010 / 2011$} \\
\hline & December & April & December & April \\
\hline Unpeeled potatoes & $284^{\mathrm{d} \mathrm{C}}$ & $121^{\mathrm{b} \mathrm{A}}$ & $145^{\mathrm{d} \mathrm{B}}$ & $112^{\mathrm{d} A}$ \\
\hline Potatoes after peeling & $247^{\mathrm{c} \mathrm{C}}$ & $110^{\mathrm{b}} \mathrm{AB}$ & $132^{\mathrm{d} \mathrm{B}}$ & $102^{\mathrm{d} A}$ \\
\hline Potatoes after blanching & $198^{\mathrm{b} \mathrm{C}}$ & $88^{\mathrm{ab} A}$ & $105^{\mathrm{c} \mathrm{B}}$ & $76^{\mathrm{c} \mathrm{A}}$ \\
\hline Potatoes after steaming and cooling & $184^{\mathrm{b} \mathrm{C}}$ & $80^{\mathrm{a}} \mathrm{AB}$ & $96^{\mathrm{c} \mathrm{B}}$ & $74^{\mathrm{c} \mathrm{A}}$ \\
\hline Pre-drying potatoes & $155^{\mathrm{a} \mathrm{C}}$ & $78^{\text {a B }}$ & $64^{\mathrm{b}} \mathrm{AB}$ & $55^{\mathrm{b} \mathrm{A}}$ \\
\hline Dehydrated potatoes & $141^{\mathrm{a} \mathrm{C}}$ & $78^{\text {a B }}$ & $43^{\mathrm{a} A}$ & $30^{\mathrm{a} A}$ \\
\hline
\end{tabular}

high to inactivate enzymes involved in the process of darkening. Blanching resulted in a significant loss in glycoalkaloids (Table 1, Fig. 2), by $28 \%$ compared to the potatoes after peeling. Glycoalkaloids dissolve in water, and $\alpha$-solanine is almost insoluble (Donald 2008). In this study, chaconine drop after blanching was greater (by $28 \%$ ) than solanine (by $27 \%$ ) (Fig. 2). According to Tajner-Czopek et al. (2008) total glycoalkaloid (TGA) content in cooked non-fragmented potatoes is reduced by approximately $22 \%$, with greater losses observed for $\alpha$ - chaconine (by $23 \%$ ) than $\alpha$-solanine (by $18 \%$ ). Another thermal process used in this study was steaming and cooling of cut/chopped and blanched potato tubers. Steaming and cooling resulted in a much lesser TGA decrease, by only about $19 \%$, this time with a greater effect on $\alpha$-solanine (a decrease $21 \%$ ) than $\alpha$-chaconine (by $17 \%$ ) (Fig. 2). During this process potatoes are exposed only to hot steam and there was no leaching factor. According to Takadi et al. (1990) the reduction of TGA in potatoes from thermal processes is only a few percent. In contrast, in this experiment, TGA concentration was significantly influenced by dehydration (Table 1, Fig. 2).
After drying potatoes for $2 \mathrm{~h}$ at $160{ }^{\circ} \mathrm{C}$, the amount of TGA decreased by $25 \%$ compared to the potatoes after blanching, with a greater decrease in $\alpha$-chaconine (by $28 \%$ ) than $\alpha$-solanine (by $23 \%$ ). High temperatures over a relatively short time had a significant impact on the content of these compounds in potatoes. Temperature within the range 165-170 ${ }^{\circ} \mathrm{C}$ are sufficient for the degradation of these compounds. These reductions are not as great as during frying french fries or chips. During drying, the dried material is exposed only to hot air, there is no factor that could leach glycoalkaloids. Thus, in the studies conducted by Friedman (2006), Pęksa et al. (2006) and Rytel et al. (2005) frying french fries and chips resulted in higher changes in TGA content (by about $40 \%$ ). According to Friedman (2006) TGA can be significantly reduced by temperatures above $170{ }^{\circ} \mathrm{C}$. In this study, further dehydration of potato pulp had no effect on reducing TGA, despite its long time (about 8 10 h) (Table 1, Fig. 2), which could have been due to the relatively low temperature of dehydration (ca. $50{ }^{\circ} \mathrm{C}$ ). The finished product contained $4.26 \mathrm{mg} \alpha$-chaconine per $100 \mathrm{~g}$

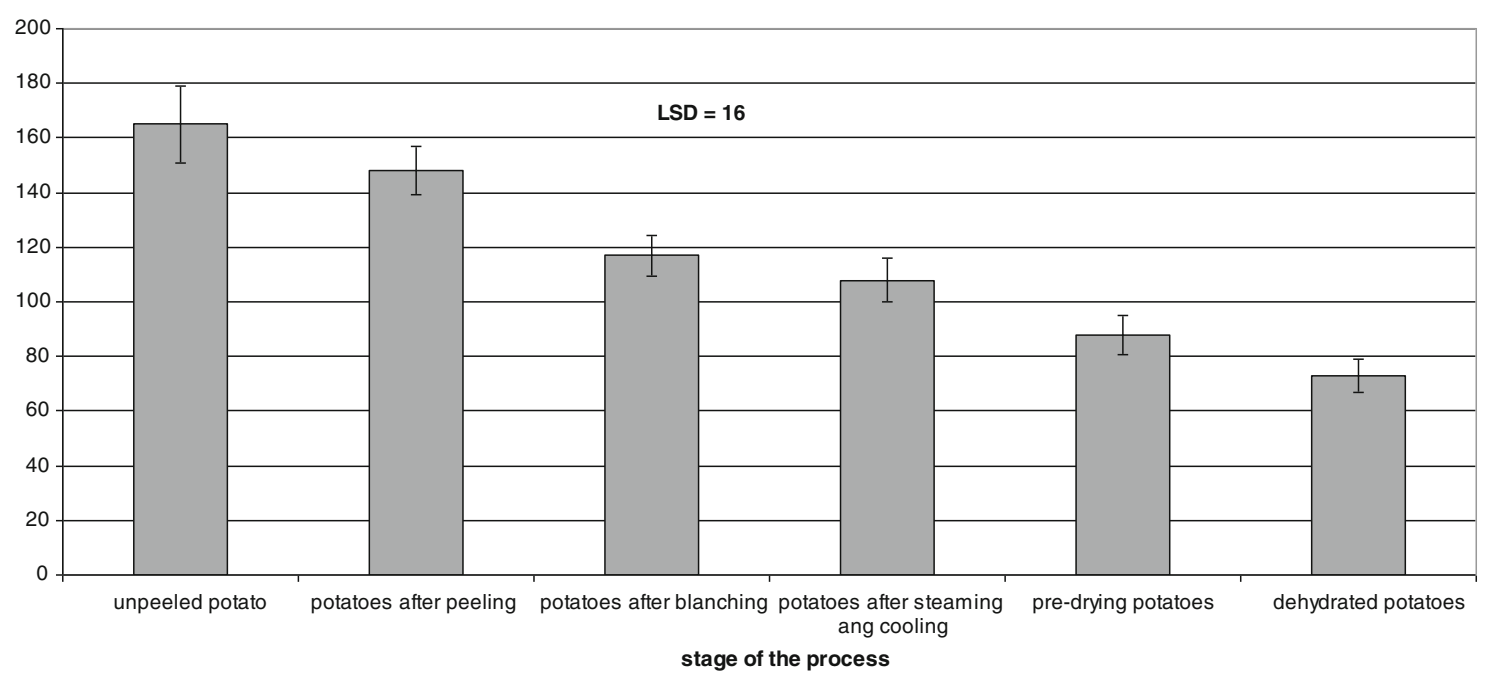

Fig. 3 Nitrates content $\left(\mathrm{NaNO}_{3} \mathrm{~kg}^{-1}\right.$ d.m.) in potatoes during dehydration of cooked potatoes (mean of 2 years). LSD - indicates significant differences between stages (Duncan test, $p<0.05$ ); \pm SD standard deviation; $n=8$ 
dry weight and $2.20 \mathrm{mg}$ of $\alpha$-solanine in $100 \mathrm{~g}$, which represents approximately $25 \%$ of the initial content of these compounds in the raw material (Fig. 2).

The production of dehydrated potato also had an impact on changes in nitrate content in semi-finished and finished product, as compared with levels in the raw material (Table 2, Fig. 3). In our test, raw potatoes contained from $112 \mathrm{mg} \mathrm{NaNO}_{3} \mathrm{~kg}^{-1}$ dry weight to $284 \mathrm{mg} \mathrm{NaNO} \mathrm{kg}^{-1}$ dry weight (Table 2). This large spread between the results depended, similar to TGA, on the date of sampling. However, the correlation was reversed - potatoes at the beginning of the storage had more than twice the nitrate content, than at the end of the storage (Table 2).

According to Cieślik (1994), storage duration has a significant impact on the nitrate content in potato tubers. In potatoes stored under appropriate conditions (temperature, humidity) and in the absence of light, the amount of nitrate decreases after several months of storage. In the process of laboratory dehydration, nitrate content decreased the most after peeling, blanching and drying (Fig. 3). Peeling resulted in a $10 \%$ nitrate reduction, which is related to the distribution of the nitrate in the potato tuber.

The largest nitrate concentration is found in the skin and just below its surface, and therefore deeper peeling results in greater nitrate loss. In the current work, potatoes were mechanically peeled to a depth of about $1.5 \mathrm{~mm}$. Similar peeling was performed by Pęssa et al. (2006) who observed a 25-28\% decrease in nitrate. Nitrate compounds dissolve well in water and are not very resistant to high temperatures (Becka et al. 1992; Cieślik 1992) and therefore thermal processes, especially those using hot water or oil, significantly reduce nitrate content in potatoes.

In our work, blanching decreased the amount of nitrate by $21 \%$ compared to potatoes after peeling (Fig. 3). According to Pęksa et al. (2006) the process of slicing, washing and blanching reduces the amount of nitrates by a total of $19-20 \%$ and according to Rytel et al. (2005) by up to about $35 \%$. Another process - steaming - did not significantly influence the losses of these compounds in potatoes (Fig. 3). Drying decreased nitrate content by $18 \%$ on average (Fig. 3). The loss of nitrate was as great as after drying potatoes at high temperatures (above $160{ }^{\circ} \mathrm{C}$ ), as during further drying at $50{ }^{\circ} \mathrm{C}$. During drying, high temperatures are not accompanied by a leaching agent (water, fat), which facilitates the removal of nitrate from potato. According to various authors (Cieślik 1992; Pęksa et al. 2006; Rytel et al. 2005) frying reduces the amount of nitrate by up to $85-89 \%$. This depends not only on temperature but also on the fineness of the material. The finer particulate material loses more nitrate (Rytel et al. 2011; Rytel 2010). In our study, the finished dehydrated potato contained on average $73 \mathrm{mg}$ $\mathrm{NaNO}_{3} \mathrm{~kg}^{-1}$ (Fig. 3).

Dried potato consumption is steadily increasing, which is associated with changes in human lifestyles. Instead of preparing our own meals ourselves, we increasingly buy more processed products: frozen products, potato concentrates and refined products. The vast majority of these products contain dehydrated potato, which is why constant monitoring of all production processes will fully regulate the content of antinutritional or toxic compounds in food.

During the laboratory production of dehydrated potato, glycoalkaloid and nitrate content in processed potatoes significantly decreased. TGA decreased most after peeling (by $30 \%)$, blanching $(28 \%)$ and pre-drying (25\%). Nitrate content decreased significantly after blanching (by $21 \%$ ) and after pre-drying (18\%). The loss of nitrate was as big after drying potatoes at high temperatures (above $160^{\circ} \mathrm{C}$ ) as during further drying at $50^{\circ} \mathrm{C}$. In the final dehydrated potato there was $4.26 \mathrm{mg} \alpha$-chaconine per $100 \mathrm{~g}$ dry weight, $2.20 \mathrm{mg} \alpha$-solanine in $100 \mathrm{~g}$, and $73 \mathrm{mg} \mathrm{NaNO} \mathrm{kg}^{-1}$.

Open Access This article is distributed under the terms of the Creative Commons Attribution License which permits any use, distribution, and reproduction in any medium, provided the original author(s) and the source are credited.

\section{References}

Amr, A., and N. Hadidi. 2001. Effect of cultivar and harvest date on nitrate $\left(\mathrm{NO}_{3}\right)$ and nitrite $\left(\mathrm{NO}_{2}\right)$ content of selected vegetables grown under open field and greenhouse conditions in Jordan. Journal of Food Composition and Analysis 14: 59-67.

AOAC. 1995. Official methods of analytical chemist, 5th ed. Washington, DC: Association of Official Analytical Chemistry.

Becka, J., B. Mica, and B. Vockal. 1992. Changes in the content of nitrate nitrogen in raw and boiled potatoes. Roslinna Vyroba 28: 181-188.

Cieślik, E. 1992. The nitrates and nitrites content in potatoes during culinary process. Przemyst Spożywczy 10: 266-267.

Cieślik, E. 1994. Nitrates and nitrites content in potato tubers after 6month storage. Polish Journal of Potato and Nutrition Science 3, 44(2): 25-29.

Cieślik, E. 1995. The effect of weather conditions on the level of nitrates in tubers of same potato varieties. Polish Journal of Potato and Nutrition Science 4 ,45(3): 11-19.

Cieślik, E. 1997. Factors affecting the content of glycoalkaloids in potato tubers. Postepy Nauk Rolniczych 5(97): 113-119.

Czerko, Z., and K. Zgórska. 2008. Storage technology of potato for food processing. Zeszyty Problemowe Postępów Nauk Rolniczych 530: 69-79.

Donald, G. 2008. Potatoes, Tomatoes, and solanine toxicity (Solanum tuberosum L., Solanum lycopersicum L.). In Medical toxicology of natural substances: Foods, fungi, medicinal herbs, toxic plants, and venomous animal, ed. D.G. Barcelux, 77-83. Heboken: John Wiley \& Sons.

Friedman, M. 2006. Potato Glycoalkaloids and metabolites: roles in the plant and in the diet. Journal of Agriculture of Food and Chemistry 54(23): 8655-8681.

Friedman, M., and L. Dao. 1992. Distribution of glycoalkaloids in potato plants and commercial potato products. Journal of Agriculture of Food and Chemistry 40: 419-423.

Friedman, M., and C.E. Levin. 2009. Analysis and biological Activities of potato glycoalkaloids, calystegine alkaloids, phenolic 
compounds, and anthocyanins. In Advances in potato chemistry and technology, ed. J. Singh and L. Kaur, 127-162. Burlington: Academic. chapter 6.

Friedman, M., and G.M. McDonald. 1997. Potato glycoalkaloids: chemistry, analysis, safety and plant physiology. Critical Reviews in Plant Sciences 16(1): 55-132.

Ginzberg, I., J.G. Tokuhisa, and R.E. Veilleux. 2009. Potato steroidal glycoalkaloids: biosynthesis and genetic manipulation. Potato Research 52: 1-15.

Haase, N.U. 2010. Glycoalkaloid concentration in potato tubers related to storage and consumer offer. Potato Research. doi:10.1007/ s11540-010-9162-1.

Hill, J.M. 1999. Nitrate toxicity: myth or reality. Bromatology Journal of Nutrition 81: 343 .

Ierna, A. 2009. Influence of harvest date on nitrate contents of three potato varieties for off- season production. Journal of Food Composition and Analysis 22: 551-555.

Knuthsen, P., U. Jensen, B. Schmidt, and K.I. Larsen. 2009. Glycoalkaloids in potatoes: content of glycoalkaloids in potatoes for consumption. Journal of Food Composition and Analysis 22: $577-581$.

Leszczyński, W. 2000. The quality of table potato. Żywność, Nauka, Technologia, Jakość 4, 25(7): 5-27.

Lewicki, P. 2008. Lexicon of the science of nutrition and human nutrition. (Ed) SGGW Warszawa, $521 \mathrm{pp}$

Lisińska, G., and W. Leszczyński. 1989. Potato science and technology, 1st ed. London, New York: Elsevier Applied Science. 391 pp.

Lisińska, G., A. Pẹksa, A. Kita, E. Rytel, and A. Tajner-Czopek. 2009. The quality of potato for processing and consumption. In: N. Yee, W. Bussel (Eds) Potato IV. Food (Special Issue) 2: 99-104.

Love, S.L., T.J. Herrman, A. Thomson-Johns, and T.P. Baker. 1994 Effect of interaction of crop management factors on the glycoalkaloid concentration of potato tubers. Potato Research 37: 77 85.

Murawa, D., T. Banaszkiewicz, E. Majewska, B. Błaszczyk, and J. Sulima. 2008. Nitrate and nitrite content in selected vegetables and potatoescommercialy available in Olsztyn. Bromatology Chemical Toxicology XLI 1: 67-71.

Ostry, V., J. Ruprich, and J. Skarkova. 2010. Glycoalkaloids in potato tubers: the effect of peeling and cooking in salted water. Acta Alimentaria 39(2): 130-135.
Pęksa, A., G. Gołubowska, E. Rytel, G. Lisińska, and K. Aniołowski. 2002. Influence of harvest date on glycoalkaloid contents of three potato varieties. Food Chemistry 78: 313-317.

Pęksa, A., G. Gołubowska, K. Aniołowski, G. Lisińska, and E. Rytel. 2006. Changes of glycoalkoaloids and nitrate contents in potatoes during chips processing. Food Chemistry 97: 151-156.

Rytel, E. 2010. Chosen pro- and anti-nutritional substances in potatoes and changes in their content during potato processing for food products. Zeszyty Problemowe Postępów Nauk Rolniczych 557: 43-61.

Rytel, E. 2012. Changes in glycoalkaloid and nitrate content in potatoes during dehydrated diceprocessing. Food Control 25: 349354.

Rytel, E., G. Gołubowska, G. Lisińska, A. Pęksa, and K. Aniołowski. 2005. Changes in glycoalkaloid and nitrate contents in potatoes during French fries processing. Journal of Agriculture of Food and Chemistry 85: 879-882.

Rytel, E., A. Pęksa, A. Tajner-Czopek, A. Kita, and G. Lisińska. 2011. Anti-nutritional compounds in potatoes, depending on the type of raw material and conditions of processing potatoes into food products. In: N. Yee, W. Bussel (Eds) Potato V. Food (Special Issue) 1: 15-22.

Saito, S.L., L.L. Sanford, and R.E. Webb. 1990. High-performance liquid chromatographic determination of glycoalkaloids in potato products. Journal of Chromatography 508: 141-147.

Șengül, M., F. Keleş, and M.S. Keleș. 2004. The effect of storage conditions (temperature, light, time) and variety on the glycoalkaloid content of potato tubers and sprouts. Food Control 15: 281-286.

Tajner-Czopek, A., M. Jarych-Szyszka, and G. Lisińska. 2008. Changes in glycoalkaloids content of potatoes destined for consumption. Food Chemistry 106: 706-711.

Tajner-Czopek A., E. Rytel, A. Kita, A. Pęksa, and K. Hamouz. 2012. The influence of thermal process of coloured potatoes on the content of glycoalkaloids in the potato products. Food Chemistry 133: $1117-1122$.

Takadi, K., M. Toyoda, Y. Fujiyama, and Y. Saito. 1990. Effect of cooking on the content of $\alpha$ - chaconine and $\alpha$-solanine of potatoes. Japanese Society for Food Hygiene and Safety 31: 67-73.

Zgórska, K., Z. Czerko, and M. Grudzińska. 2006. The effect of some selected factors on the content of glycoalkaloids in potato tubers. Żywność, Nauka, Technologia, Jakość 1(46): 229-234. 